UNDERGROUND MINING ENGINEERING 35 (2019) 81-91 $\quad$ UDK 62

\title{
SEPIOLITE - A BY-PRODUCT OF EXPLOITATION AS A POTENTIAL RAW MATERIAL IN SERBIAN INDUSTRY
}

\author{
Radmila Gaćina $^{1}$, Katarina Urošević ${ }^{1}$, Jelena Zakonovićc
}

Received: December 3, 2019

Accepted: December 25, 2019

\begin{abstract}
This paper gives a brief overview of the sepiolite deposits, the basic properties, and the possibilities of using this mineral. Particular attention is paid to sepiolites from domestic production, especially the use of sepiolites suitable for the development of small businesses and technologies, with a focus on environmental protection. Aim of this paper is to point out importance of this mineral and to draw attention to the use of domestic raw materials.

With appropriate mechanical and chemical pretreatments, sepiolite is shown to be useful in following applications: NCR paper, drilling fluids, absorbents, carriers for chemicals, animal nutrition, agriculture, decolorising agents, cosmetics and pharmaceutical uses, etc.
\end{abstract}

Keywords: sepiolite; by-product; small-scale mine; marginal costs;

\section{INTRODUCTION}

Clays and clay minerals have demonstrated to be interesting materials due to their high adsorption capability, colloidal properties as well as the possibility of tailoring their surface characteristics to provide specific solutions for a wide variety of industrial applications (Jones and Galan, 1988). Since sepiolite is naturally occurring, it is relatively cheap and environmentally friendly material with favorable properties, which makes it very attractive in industrial and in academic field.

Sepiolite was named in 1847 by Ernst Friedrich Glocker from the Greek, "sepion," cuttlefish bone, because of its low density and porous, bone like appearance, also formerly known as Meerschaum (sea froth), is a non-swelling, lightweight, porous clay with a large specific surface area. The high surface area and porosity, as well as the unusual particle shape of this clay account for its outstanding sorption capacity and colloidal properties that make it a valuable material for a wide range of applications.

\footnotetext{
${ }^{1}$ University of Belgrade - Faculty of Mining and Geology

${ }^{2}$ Metalfer, d.o.o. Bulevar Mihajla Pupina 115 A 11000 Belgrade, Serbia Emails:katarina.urosevic@rgf.bg.ac.rs; jelena.zakonovic@metalfer.net;radmila.gacina@rgf. $\underline{\mathrm{rs}}$
} 
Due to its fibrous morphology and surface characteristics, it is considered an excellent reinforcement in polymer-based nanocomposites (Bokobza et al., 2004; Ruiz-Hitzky et al., 2013; Cobani et al., 2019). Peculiar characteristic of sepiolite are also useful in photocatalysis (Aranda et al., 2008), plasmonic properties (Pecharroman et al., 2009), as well in heavy metal adsorption (Dogan at al., 2008), as vaccine support (Pecharroman et al., 2009), electronic conductor (Gomez-Aviles et al., 2007), metallic nanoparticle support with biocide (Cubbilo et al., 2006), for improvement of mechanical properties of paper (Janković-Častvan, 2016).

\section{OVERVIEW OF PREVIOUS RESEARCH}

\subsection{Sepiolite deposits}

There are very few commercial deposits in the world. Most of the world production of sepiolite comes from deposits of sedimentary origin located in Spain (around 95\% of world production). Sepiolite deposits except in Spain, are known in Turkey, China, Japan, England, Africa (Tanzania and Kenya), America (Nevada and California). The purest natural sepiolite comes from Madagascar, from Ampandradova deposit. Figure 1 shows map of localities of sepiolite deposits, around the world.

Sepiolite deposits are classified according to structural-morphological criteria by which there are two types of deposits - wired and layered. The wire type of sepiolitic deposits consists of wires and nests that are irregularly accumulated in the magmatic rocks, while the layered type consists of layers, lenses and nodules of minerals in sedimentary series of younger basins near serpentine rocks. The world's largest layered type deposits are in Turkey and biggest wire-type sites are located in the US and Tanzania. The world production of sepiolite is estimated by the USGS $^{3}$ to be about 400,000 tons (Murray, 2002).

\footnotetext{
${ }^{3}$ USGS - United States Geological Survey
} 


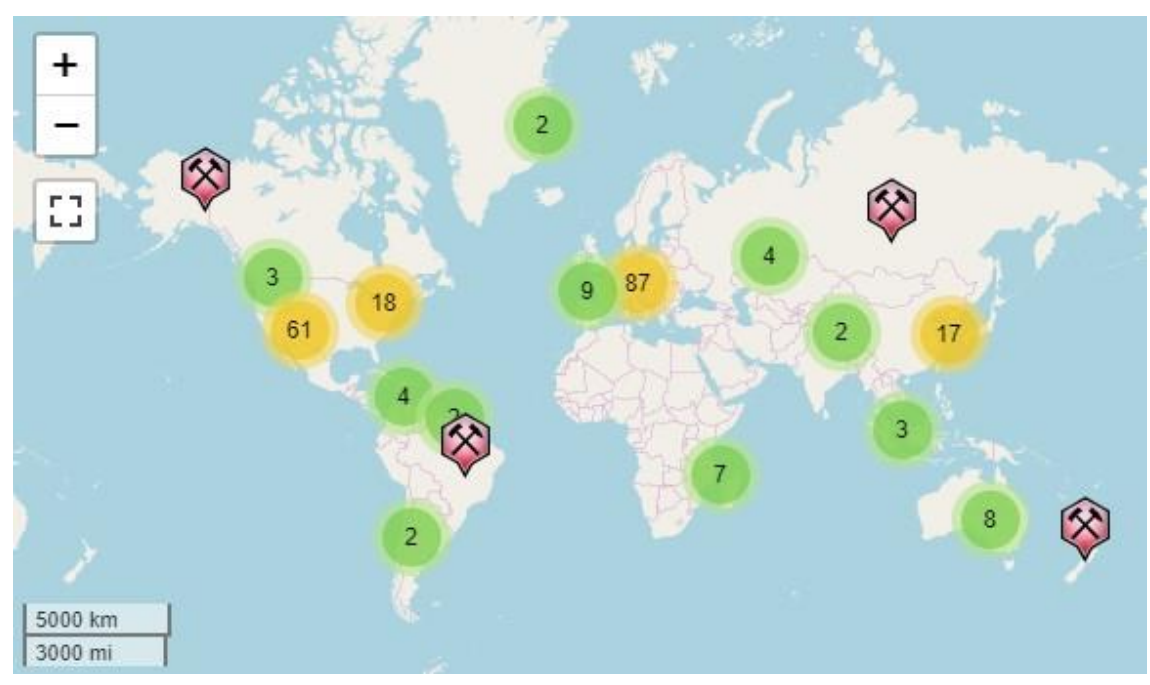

Figure 1 Sepiolite deposits in world, Source: www.mindat.org

In our country, sepiolite in the Pranjani, Neogene basin belong to the layers type, while other deposits can be classified as wire type. Besides well-known vein and stockwork deposits in ultrabasites (as Brezak, Milićevci, Koviljača, Ražana, Liska, Krive strane, Masnica, Čavlovac, Bogutovac, Trnava and Goleš) new types of magnesite deposits were discovered and studied in Serbia: sedimentary or Bela Stena type in freshwater Neogene basins (as Bela Stena, Šilopaj, Kačer, Kremna and Beli Kamen) and detritial type in freshwater Neogene basins, too (in Ražana, Pranjani and Čačak-Kraljevo Miocene basins) and Quaternary placers (around magnesite deposits of other genetic types) (Ilić at al., 2010). In Figure 2 are presented two types of sepiolite deposits in Serbia.

In the village of Andrići, sepiolite layer is found in the coastal sedimentary series Miocene. The excavation revealed that this layer extends over a length of about 100 meters and has a thickness of $1.5-2.2$ meters. The sepiolite deposit of Slovići is located in the Zlatibor ultrabasic Massive and represents a wire magnesite bearing. Sepiolites occurs within the larger magnesite wires, in the form of separated wires, lenses and irregular accumulations. Sepiolite is closely associated with magnesite in all these deposits, so this deposits should be treated as unique, complex magnesia-sepiolite deposits, exploration and exploitation need to be carried out simultaneously.

In the Pranjani basin, sepiolite and paligorskite are found in peripheral sediments. So far, they have not been registered in the central parts of the basin, leading to the conclusion that they are silicon, magnesium and aluminum were deposited relatively quickly. Then, they occur together with trioctahedral $\mathrm{Mg}$-smectites and dolomite, suggesting that the magnesium yield was continuous, and there were periods of silicon deficiency and of aluminum in solution (Lazarević, 2012). 


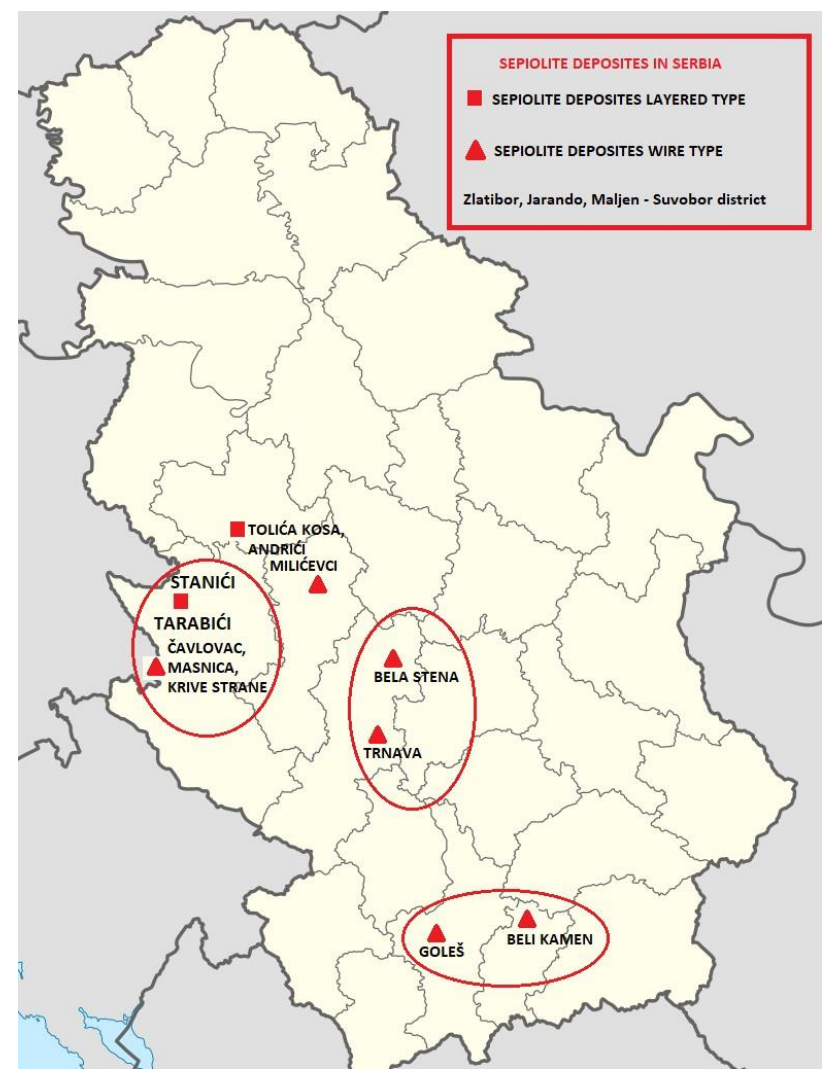

Figure 2 Sepiolite deposites in Serbia

\subsection{Basic properties of sepiolite}

Chemical formula of sepiolite is $\mathrm{Mg}_{4} \mathrm{Si}_{6} \mathrm{O}_{15}(\mathrm{OH})_{2} \cdot 6 \mathrm{H}_{2} \mathrm{O}$, hydrated magnesium silicate, has a large specific surface area (up to $350 \mathrm{~m}^{2} / \mathrm{g}$ ) and high porosity, and these characteristics make it a good adsorbent for liquids and gases. Color of sepiolite varies from white to greyish to slightly colored. The fibers consist of talc-like ribbons alternated by channels along the fiber axes (Radojević at al. 2002). Figure 3 shows variation colors of sepiolite from deposit Eshisehir located in Tukey.

Sepiolite is the result of the interaction between silica and magnesium-bearing solutions in an environment with suitable physical-chemical conditions (mostly $\mathrm{pH}$ and salinity). The physico-chemical conditions of the environment control the formation of the magnesian clay mineral, also determining its fibrous or laminar nature and, consequently, its composition (Galan and Pozo, 2011). These conditions occur in specific continental sedimentary environments where they give rise to sepiolite deposits of commercial interest. Basic structure of sepiolite is shown in Figure 4. 
Unlike other clays, the individual particles of sepiolite have a needle-like morphology. Its structure can be described as a quincunx (an arrangement of five objects, so placed that four occupy the corners and the fifth the center of a square or rectangle) of talc-type sheets separated by parallel channels. This chain-like structure produces needle-like particles instead of plate-like particles like other clays.

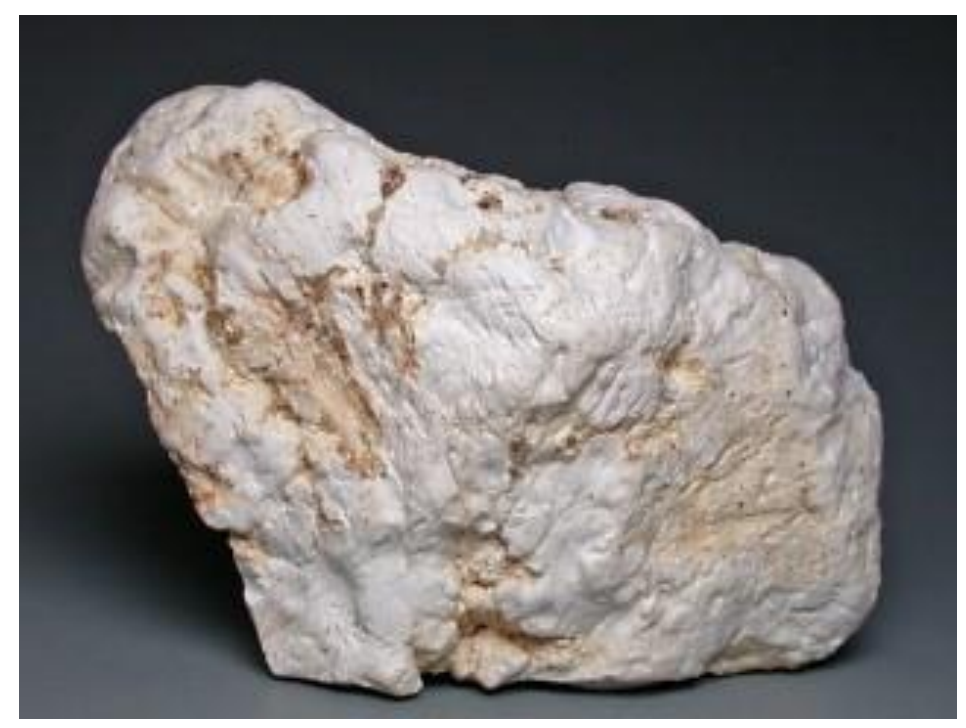

Figure 3 Sepiolite from Eskisehir

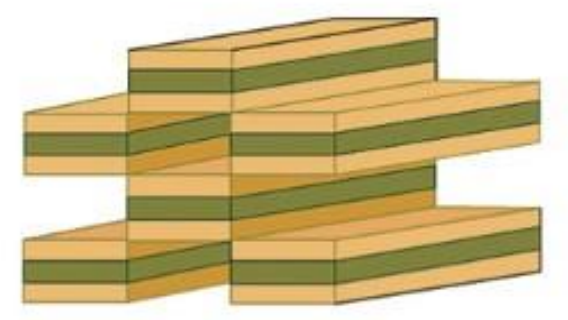

\section{TETRAHEDAL SHEETS}

\section{OCTAHEDRAL SHEETS}

Figure 4 Schematic mineral structure of sepiolite Turkey (www.weblio.jp)

Sepiolites from different beds also have different morphological characteristics and characteristics such as: fiber dimensions, beam dimensions, specific surface area, impurities present, thermal properties etc. Sepiolite can be formed in lake and marine environments, in soil conditions or in surface decomposition of rocks. The process of sepiolite formation is not enough clarified. Any attempt to obtain individualized fibers from natural sepiolite micrometric aggregates would profit the development of 
technological applications, taking advantage of the silanol-based chemistry and the nanometric diameter of isolated fibers (Lescano et al., 2014).

Usage of sepiolite from Serbia was proved recently in 2012, only for the sepiolite (i.e. sepiolite clay) from the Tolica Kosa deposit, by industrial-technological testing of a technological sample. This testing, guided by the InterCer Company d.o.o. from Belgrade, demonstrated that, in appropriate industrial facilities and by using an appropriate technological treatment, it is feasible to get quality products (in the first place sorbents, additives for animal food and the others) from the sepiolite clay of the Tolica Kosa deposit which have application in Serbian industry (Ilić et al., 2015).

Geological investigations have uncovered and explored many deposits of sepiolite, both of wireline and layered structural-morphological type, and some of the known deposits have been afresh investigated. All sepiolite concentrations, as well as the previously explored deposits, were studied geologically in detail and samples were taken from the furrow method, which were subjected to mineralogical, chemical and laboratory technological tests, noting that the Goles and Trnava deposits are now inaccessible (therefore the mining works are ruined).

The most significant results of sepiolite research in Serbia are:

- All newly discovered sepiolite concentrations were sampled by a furrow method and sent for further testing (only in case of Tolica Kosa sample was taken by a massive method $5 \mathrm{t}$ )

- Mineralogical studies show that in addition to the dominant sepiolite, carbonates, silicon, serpentines and chlorites also occur. Microscopic, X-ray, infrared spectroscopic, thermogravimetric and differential thermal tests were performed. Chemical tests indicate that these deposits are sepiolite clays, a very pure sepiolite with little admixture.

- Chemical tests indicate that these deposits are sepiolite clays, a very pure sepiolite with little admixture

- Technological tests has been determined: the behavior of sepiolite in the preparation, processing and finalization of products, as well as the possibilities of application in the economy in Serbia.

\section{POSSIBILITIES OF APPLICATION IN INDUSTRY}

Commercial sepiolite based products became available in Spain in the middle twentieth century, and are now present in markets in China, Turkey and United States (Galan et al., 1984). Numerous studies are still being done in order to find new possibilities for application. Common industrial applications of sepiolite are listed in Table 1. 
Table 1 Main application of sepiolite in industry

\begin{tabular}{|c|c|}
\hline Moisture control & $\begin{array}{l}\text { Sepiolite adsorbs excess humidity preventing condensation, corrosion, the } \\
\text { proliferation of microorganisms and unpleasant stenches. }\end{array}$ \\
\hline $\begin{array}{l}\text { Industrial } \\
\text { absorbent }\end{array}$ & $\begin{array}{l}\text { Sepiolite absorbs liquid spills and leaks keeping work and transit areas dry and } \\
\text { safe. Sepiolite is a non-flammable material with high liquid absorbing capacity, } \\
\text { suitable mechanical strength of the granules even in wet conditions, and } \\
\text { chemical inertness which avoids reaction with absorbed liquids }\end{array}$ \\
\hline Bitumens & $\begin{array}{l}\text { Sepiolite allows controlling the rheological properties in heat application } \\
\text { systems, improving fire resistance. It also improves the stability and the } \\
\text { application in emulsions and asphalt in solvent products }\end{array}$ \\
\hline \multirow{4}{*}{$\begin{array}{l}\text { Rheological } \\
\text { additives }\end{array}$} & - $\quad$ for aqueus systems \\
\hline & $\begin{array}{l}\text { Sepiolite provides stability, pseudoplasticity and thixotropy in different } \\
\text { applications as paints, adhesives, mastics and sealants. }\end{array}$ \\
\hline & - $\quad$ for organic systems \\
\hline & $\begin{array}{l}\text { Organically modified sepiolite allows controlling the rheological behavior of } \\
\text { different solvent-based systems as paints, greases, resins and inks enhancing } \\
\text { their stability under a wide temperature range and making for easier application }\end{array}$ \\
\hline Litters for pets & $\begin{array}{l}\text { Pet litters based on sepiolite are popular due to its light weight, high liquid } \\
\text { absorption and stench control characteristics }\end{array}$ \\
\hline Animal feedstuffs & $\begin{array}{l}\text { In the EU, sepiolite is registered as a technological additive for animal feed (E- } \\
562 \text { ) Sepiolite products are used as binders and anti-caking of freeflowing } \\
\text { additives as well as excipient of supplements. Sepiolite-based rheological } \\
\text { products are also used as suspending additives in liquid feeds for pigs and } \\
\text { ruminants. }\end{array}$ \\
\hline Waste treatment & $\begin{array}{l}\text { Sepiolite absorbs toxic and hazardous wastes in stabilization or inertisation } \\
\text { treatments }\end{array}$ \\
\hline Polymer fillers & $\begin{array}{l}\text { The use of sepiolite fillers improve processing, dimensional stability, } \\
\text { mechanical strength and thermal resistance }\end{array}$ \\
\hline \multirow[t]{2}{*}{ Construction } & - $\quad$ additives \\
\hline & $\begin{array}{l}\text { Sepiolite provides thixotropy making for easier application, preventing sagging } \\
\text { and providing better quality finish in mortars, plasters and concrete. It is also } \\
\text { used as a processing aid in the manufacture of fibre-reinforced cement products }\end{array}$ \\
\hline Roof panels & $\begin{array}{l}\text { Sepiolite improves binding of the components while increasing the fire } \\
\text { resistance }\end{array}$ \\
\hline Fertilisers & $\begin{array}{l}\text { Sepiolite improves stability and components suspension of fluid fertilisers in } \\
\text { spraying or fertirrigation applications }\end{array}$ \\
\hline Houshold uses & $\begin{array}{l}\text { Sepiolite have wide range of domestic application such as: use in ashtrays to } \\
\text { avoid smoke stenches, control of liquid leakages and stenches in dustbins, } \\
\text { stenches removal in refrigerators, and moisture control, containment of } \\
\text { accidental liquid spillages. }\end{array}$ \\
\hline Thickeners & $\begin{array}{l}\text { Sepiolite is a colloidal, asbestos-free thixotrope, anti-settling agent and } \\
\text { thickenr gor watery suspension systems, high and medium polar solvents, for } \\
\text { solvent-free and solvent-less resin and polymer systems. }\end{array}$ \\
\hline Bleaching agent & For mineral and vegetables oils, fets, paraffins, wine, butter \\
\hline
\end{tabular}


On the market are available products called: Pangel, Pansil, Aid Plus, Hexal, Milcon, ML 70DSA and others, containing from 75 to 95 wt. \% sepiolite and there may be different granulations. The most important are the 6/30 mesh granulation products, which used as sorbents, granulation 30/60, 60/100, 120/400 and 400 mesh, used as pesticide carriers and coloring agents. High purity sepiolites (usually over $95 \%$ ) are used as catalyst supports or rheological additives. Figure 5 shows different phases of processing sepiolite for market.

Sepiolites, particularly those classified as gel clays, are traded in a global market. Absorbent grades are produced and used in regional and local markets. No large multinational company is involved in the production of these clays.

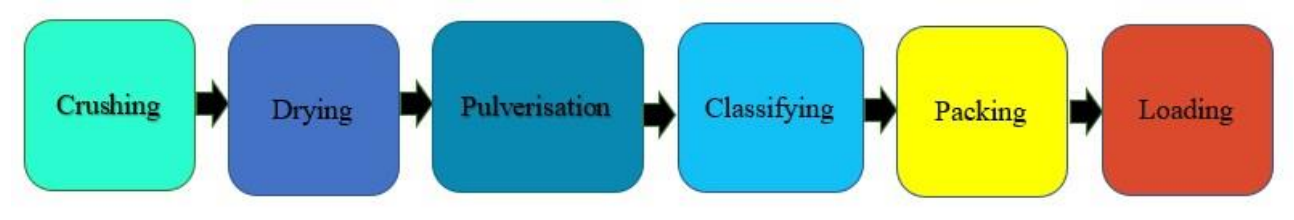

Figure 5 Sepiolite processing for market

Sepiolite also has significant applications in the field of environmental protection, primarily for removal of heavy metal ions from water and soil. Studies have shown that sepiolite in significantly absorbs $\mathrm{Cu}^{2+}, \mathrm{Zn}^{2+}, \mathrm{Cd}^{2+}, \mathrm{Co}^{2+}$ and $\mathrm{Pb}^{2+}$ ions.

In the foundry industry, the addition of a small amount of sepiolite to the mold sand increases the strength of the mold in the raw state and reduces the ultimate strength after casting, which facilitates its removal from the casting. By adding sepiolite to refractory coatings for sand molds, cores and refractory coatings, the coating properties are improved.

On the side of the health aspect, the use of sepiolite is completely safe, including epidemiological, in vitro and in vivo studies. Due to its non-toxicity and safety for human health, sepiolite is an important substitute for carcinogenic asbestos. Sepiolite have been proposed for pharmaceutical applications including tablet manufacture, slow release systems, in combination with drugs for cancer therapy, being as adjuvants, and, in general terms, for diverse therapy in humans (Toledo-Magana, et al., 2015).

\section{CONCLUSION}

While commercial deposits of sepiolite are rare, this mineral occurs relatively frequently in soil and sediments. Sepiolite is a natural mineral that is widespread and accessible, so from that reason it's affordable price. There are numerous branches of science and industry in which sepiolite has been applied, and with the development of technology, new research directions are opened daily to the most efficient application of this mineral. 
Despite the wide application of sepiolite in a variety of industrial processes (when compared with other sorbent systems) it has relatively low surface acidity, narrow channels, low surface area, and poor thermal stability. The adsorption performance of modified sepiolite are better than that of natural sepiolite, and studies have shown that the specific surface area can be increased significantly. The most significant areas for new products based on sepiolite are in environmental protection and agriculture.

Geological surveys of sepiolites in Serbia have shown that there are two structuralmorphological types of sepiolite deposits in our country: wire type in ultrabasic rocks (Goleš, Trnava, Milićevci, Čavlovac, Masnica, Krivni sides and Slovici) and layered type in sedimentary series of Miocene basins (deposits of Tolića kosa, Andrići, Stanići and Šilopaj) and that deposits contain significant concentrations of sepiolite possessing favorable adsorption and other properties (primarily catalytic and rheological).

Previous studies have shown that sepiolite clay can be used in appropriate industrial plants and technological processes get quality products (primarily sorbents, animal feed additives, in paper industry). This product based on sepiolite can be different sizes (granules and powder), with different characteristics and different purposes, which can be used in various industries in our country.

One of the directions of mining development in Serbia, could be opening and operations of so-called small-scale mines, such as magnesite deposits with accompanying sepiolite. Mineral mining exists all over the world in small-scale mines, so it could be applicable in Serbia. Small deposits, in this case sepiolite deposits, require small investments in the cours of exploitation and relatively short period of time needed for prospecting. A number of deposit are partially or totally prospected and by choosing adequate economic analysis could be used.

\section{Acknowledgment}

Authors would like to acknowledge Ministry of Education, Science and Technological Development of Republic of Serbia (Project No. 33039). We thank the Ministry for the support.

\section{REFERENCES}

ARANDA, P. et al. (2008) Titania-sepiolite nanocomposites prepared by a surfactant templating colloidal route. Chem. Mater. 20, pp. 84-91.

BOKOBZA, L. et al. (2004) Fibre reinforcement of elastomers: nanocomposites based on sepiolite and poly (hydroxyethyl acrylate). Polym. Int., 53, pp. 1060-1065. 
COBANI, E. et al. (2019) Hybrid Interface in Sepiolite Rubber Nanocomposites: Role of Self-Assembled Nanostructure in Controlling Dissipative Phenomena. Nanomaterials, 9(4), pp. 485-486.

CUBILLO, E.A. et al. (2006) Antibacterial activity of copper monodispersed nanoparticles into sepiolite. Journal of Material Scence, 41, pp. 5208-5212.

GOMEZ-AVILES, A. et al. (2007) Functionalized carbonsilicates from caramelsepiolite nanocomposites. Angew. Chem. Int. Ed. 46, pp. 923-925.

GALAN E. and POZO M. (2011) Palygorskite and Sepiolite Deposits in Continental Environments. Description, Genetic Patterns and Sedimentary Settings. In Emilio Galan and Arieh Singer, editors: Developments in Clay Science, 3, Amsterdam, The Netherlands, pp. 125-173.

ILIĆ, M. et al. (2015) Sepiolit iz ležišta u Srbiji kao industrijski mineral. Tehnika rudarstvo, geologija i metalurgija, 66, pp. 957-963.

ILIĆ, M. et al. (2010) Magnesite deposits of Serbia: An overview. Geologica Balkanica, 39, pp. 163, [Online] Available from: https://www.geologicabalcanica.eu /journal/39/12/ pp. 163 [Accessed 5/11/2019]

JANKOVIĆ-ČASTVAN, I. (2016) The properties of sepiolite based nanostructured composite materials and their applications in paper industry. Doctoral dissertation, (in Serbian), University of Belgrade, Faculty of Technology and Metallurgy, [Online] Available from: http://nardus.mpn.gov.rs/bitstream/handle/123456789/7658/Disertacija 7847.pdf? sequence $=1 \&$ isAllowed $=y$ [Accessed 5/6/2019]

JONES, B.F. and GALAN, E. (1988) Sepiolite and palygorskite. In: Bailey, S.W. (Ed.), Hydrous Phyllosilicates. Reviews in Mineralogy, 16. Min. Soc. Amer., Washington, pp. 631-674.

LAZAREVIĆ, S. (2012) Styding impact of the different modification procedure on physical-chemical characteristics and sorption properties of sepiolite. Doctoral dissertation, (in Serbian), University of Belgrade, Faculty of Technology and Metallurgy, [Online] Available from: https://fedorabg.bg.ac.rs/fedora/get/o:7208 /bdef:Content/get [Accessed 7/10/2019]

LESCANO, L. et al. (2014) Alternative methodologies for sepiolite defibering. Applied Clay Science, 95, Elsevier, pp. 378-382 [Online] Available from: https://digital.cic.gba.gob.ar/bitstream/handle/11746/4548/11746 4548.pdfPDFA.pdf?s equence $=1 \&$ isAllowed $=y$ [Accessed 20/11/2019]

MURRAY, H. (2002) Industrial clays Case Study. [Online] Available from: https://pubs.iied.org/pdfs/G00556.pdf? [Accessed 10/10/2019] 
PECHARROMAN, C. et al. (2009) Bionanocomposites as new carriers for Influenza vaccines. Adv. Mater. 21, pp. 4167-4171.

RUIZ-HITZKY, E. et al. (2013) Fibrous clay mineral polymer nanocomposites. In: Bergaya, F., Lagaly, G. (Eds.), The Handbook of Clay Science. Elsevier, United Kingdom, pp. 721-741.

RADOJEVIĆ, M. et al. (2002) Study od sepiolite from Goleš (Kosovo, Yugoslavia). I. Sorption capacity. Journal of the Serbian Chemical Society, 67(7) pp. 489-497.

TOLEDO-MAGANA, Y. et al. (2015) Effect of Clinoptilolite and Sepiolite Nanoclays on Human and Parasitic Highly Phagocytic Cells. BioMed Research International, 2015, Article ID 164980, 12 pages [Online] Available from:

http://downloads.hindawi.com/journals/bmri/2015/164980.pdf [Accessed 20/11/2019]

www.ima-europe.eu [Online] Available from: https://www.ima-europe.eu/sites/imaeurope.eu/files/minerals/Sepiolite_An-WEB-2011.pdf [Accessed 15/6/2019]

www.mindat.org [Online] Available from: https://www.mindat.org/min-3621.html [Accessed 20/10/2019] 